\title{
PENGARUH PERTUMBUHAN EKONOMI DAN USAHA MIKRO KECIL MENENGAH (UMKM) TERHADAP PENDAPATAN ASLI DAERAH (PAD) DI KABUPATEN BANGKALAN
}

\author{
Lutfiyah, Pascasarjana Universitas Negeri Surabaya \\ lutfiyahfatmawati@yahoo.com
}

\begin{abstract}
ABSTRAK
Penelitian ini bertujuan untuk menganalisis pengaruh pertumbuhan ekonomi terhadap Pendapatan Asli Daerah (PAD) di Kabupaten Bangkalan, menganalisis pengaruh UMKM terhadap Pendapatan Asli Daerah (PAD) di Kabupaten Bangkalan, menganalisis pengaruh pertumbuhan ekonomi dan UMKM terhadap Pendapatan Asli Daerah (PAD) di Kabupaten Bangkalan. Penelitian menggunakan pendekatan kuantitatif. Populasi dalam penelitian ini adalah pertumbuhan ekonomi, Usaha Mikro Kecil Menengah (UMKM) dan Pendapatan Asli Daerah (PAD) Kabupaten Bangkalan. Sampel penelitian ini adalah pertumbuhan ekonomi, Usaha Mikro Kecil Menengah (UMKM) dan Pendapatan Asli Daerah (PAD) tahun 2004-2013. Jenis pengambilan sampel yang digunakan dalam penelitian ini adalah purposive sample. Adapun metode pengumpulan data yang digunakan adalah metode dokumentasi. Sedangkan metode analisis menggunakan teknik analisis regresi linier berganda. Hasil penelitian menunjukkan bahwa secara parsial pertumbuhan ekonomi berpengaruh signifikan terhadap pendapatan asli daerah Kabupaten Bangkalan. Usaha mikro kecil menengah tidak berpengaruh signifikan terhadap pendapatan asli daerah Kabupaten Bangkalan. Sedangkan secara simultan pertumbuhan ekonomi dan usaha mikro kecil menengah berpengaruh signifikan terhadap pendapatan asli daerah Kabupaten Bangkalan.
\end{abstract}

Kata Kunci: Pertumbuhan Ekonomi, Usaha Mikro Kecil Menengah (UMKM) Pendapatan Asli Daerah Kabupaten Bangkalan

\section{ABSTRACT}

This study aims to (1) analyze the influence of economic growth on revenue (PAD) in Bangkalan, (2) analyze the effect of Micro Small Medium Enterprises to revenue (PAD) in Bangkalan, (3) analyze the effect of economic growth and Micro Small Medium Enterprises to revenue (PAD) in Bangkalan. The research uses a quantitative approach. The population in this study is economic growth, Micro Small Medium Enterprises (SMEs) and revenue (PAD) Bangkalan. The sample was economic growth, Micro Small Medium Enterprises (SMEs) and revenue (PAD) in 2004-2013. The type of sampling used in this study is purposive sample. The data collection method used adallah documentation method. While the methods of analysis using multiple linear regression analysis technique. The results showed that the economic growth partially significant effect on local revenue Kabupaten Bangkalan. Small and medium micro enterprises had no significant effect on revenue Bangkalan. While the simultaneous growth of small and medium micro enterprises have a significant effect on revenue Bangkalan.

Keywords: Economic Growth, Micro Small Medium Enterprises (SMEs) Local Revenue Kabupaten Bangkalan. 


\section{PENDAHULUAN}

Pelaksanaan otonomi daerah yang dititikberatkan pada Daerah Kabupaten dan Daerah Kota dimulai dengan adanya penyerahan sejumlah kewenangan (urusan) dari pemerintah pusat ke pemerintah daerah yang bersangkutan. Penyerahan berbagai kewenangan dalam rangka desentralisasi ini tentunya harus disertai dengan penyerahan dan pengalihan pembiayaan. Sumber pembiayaan yang paling penting adalah sumber pembiayaan yang dikenal dengan istilah Pendapatan Asli Daerah di mana komponen utamanya adalah penerimaan yang berasal dari komponen pajak daerah dan retribusi daerah. Pendapatan Asli Daerah (PAD) sebagai salah satu penerimaan daerah mencerminkan tingkat kemandirian daerah. Semakin besar PAD maka menunjukkan bahwa daerah itu mampu melaksanakan desentralisasi fiskal dengan baik dan ketergantungan terhadap pemerintah pusat berkurang.

Dalam UU No.32/2004 disebutkan bahwa untuk pelaksanaan kewenangan Pemerintah Daerah, Pemerintah Pusat akan mentransfer Dana Perimbangan yang terdiri dari Dana Alokasi Umum (DAU), Dana Alokasi Khusus (DAK), dan bagian daerah dari Dana Bagi Hasil yang terdiri dari pajak dan sumber daya alam. Disamping dana perimbangan tersebut, Pemerintah Daerah mempunyai sumber pendanaan sendiri berupa Pendapatan Asli Daerah (PAD), pembiayaan, dan lainlain pendapatan. UU No. 33/2004 tentang perimbangan Keuangan antara Pemerintah Pusat dan Pemerintah Daerah, disebutkan bahwa pendapatan asli daerah adalah pendapatan yang diperoleh daerah yang dipungut berdasarkan peraturan daerah sesuai dengan peraturan perundang-undangan. Pada pasal 3, disebutkan bahwa PAD bertujuan memberikan kewenangan kepada pemerintah daerah untuk mendanai pelaksanaan otonomi daerah sesuai dengan potensi daerah sebagai perwujudan desentralisasi. Kebijakan penggunaan semua dana tersebut diserahkan kepada Pemerintah daerah. Seharusnya dana transfer dari Pemerintah Pusat diharapkan digunakan secara efektif dan efisien oleh Pemerintah Daerah untuk meningkatkan pelayanannya kepada masyarakat. Kebijakan penggunaan dana tersebut sudah seharusnya pula secara transparan dan akuntabel.

Menurut Suryana(2000) keberhasilan suatu daerah dalam usaha membangun ekonomi daerah dipengaruhi beberapa faktor ekonomi, meliputi: sumber daya manusia(labor supply, education, discipline, motivation); sumber daya(natural resources); pembentukan modal( capital formation); teknologi dan kewirausahaan(technology and entrepreneurship). Selain itu juga beberapa variabel yang mempengaruhi $\mathrm{PAD}$ tersebut diantaranya variabel pertumbuhan ekonomi dan usaha mikro kecil menengah penduduk daerah tersebut.

Pertumbuhan ekonomi suatu daerah merupakan proses pertumbuhan ekonomi secara berkesinambungan menuju keadaan yang lebih baik selama periode tertentu. Pertumbuhan ekonomi juga dapat diartikan sebagai proses kenaikan kapasitas pendapatan daerah. Perekonomian dikatakan mengalami mengalami pertumbuhan apabila tingkat kegiatan ekonomi meningkat dari satu dari satu periode ke tahun berikutnya, yang berarti jumlah barang dan jasa yang dihasilkan bertambah besar.

Pertumbuhan ekonomi menjadi kunci sebuah wilayah. Pulau Madura yang menjadi bagian dari provinsi Jawa Timur, mengalami kondisi yang kurang menguntungkan. Laju pertumbuhan ekonomi lambat dan pendapatan perkapita 
tertinggal. Salah satunya Kabupaten Bangkalan yang memiliki luas $1.261,81 \mathrm{~km}^{2}$ mempunyai penduduk sejumlah 919.002 jiwa dengan komposisi 439.054 penduduk laki-laki dan 479.948 jiwa perempuan. Dengan kondisi tersebut maka kepadatan penduduk sebesar $1.038 \mathrm{jiwa} / \mathrm{km}^{2}$. Sedangkan pertumbuhan penduduk sebesar 1,74\% per tahun. (Statistik daerah Kabupaten Bangkalan 2013). Pertumbuhan Ekonomi sering diukur dengan menggunakan Produk Domestik Regional Daerah/PDRB

Menurut Sasana, 2009 menunjukkan hasil estimasi antara desentralisasi fiskal terhadap pertumbuhan ekonomi di kabupaten/kota Provinsi Jawa Tengah, menunjukkan bahwa desentralisasi fiskal berpengaruh positif terhadap pertumbuhan ekonomi. Menurut Gunantara dan Dwirandra (2014), dalam penelitiannya menunjukkan hasil uji simultan menunjukan PAD, DAU, dan Belanja Modal berpengaruh secara simultan terhadap Pertumbuhan Ekonomi.

Salah satu penyebab kegagalan dalam pencapaian pertumbuhan ekonomi dan pembangunan ekonomi suatu negara karena kurangnya entrepreneurship baik dalam level individu, organisasi dan masyarakat. Kewirausahaan sangat berperan dalam pembangunan ekonomi. Untuk meningkatkan pembangunan ekonomi, maka kewirausasahaan harus tertanam dalam diri seorang yang akan mendirikan suatu usaha baik usaha mikro, kecil maupun usaha menengah. Hal itu disebabkan karena pemerintah pusat maupun pemerintah daerah tidak mampu menyediakan lapangan kerja sepenuhnya untuk merekrut para pencari kerja. Ada beberapa faktor yang melatar belakangi seseorang untuk berwirausaha, misalnya lingkungan keluarga, pendidikan, riwayat pekerjaan dan usia. Banyak orang menyatakan bahwa tingkat pendidikan para wirausaha, agak rendah dibandingkan dengan rata-rata populasi masyarakat. Hal itu dapat kita lihat pada masyarakat madura yang memiliki jiwa kewirausahaan yang tinggi meskipun mereka memiliki pendidikan yang rendah, namun karena keuletan dan kerja keras masyarakat madura, mereka mampu berwirausaha dalam berbagai bidang dan terbukti sukses. Akan tetapi hal ini tidak begitu signifikan, karena tingkat pendidikan juga penting bagi wirausaha dalam menjaga kontinuitas usahanya dan mengatasi segala masalah yang dihadapi diperlukan tingkat pendidikan yang memadai. Akan tetepi seseorang yang memiliki kewirausahaan tinggi dan digabung dengan kemampuan manajerial yang memadai akan menyebabkan dia sukses dalam usahanya (Priyo, 2006)

Adapun fenomena yang terjadi yakni dinas UMKM yang bergabung dengan dinas koperasi bekerjasama dengan memberikan suntikan dana kepada beberapa dinas di Kabupaten Bangkalan diantaranya dinas pertanian, peternakan, perikanan, restoran, industri kerajinan tangan dan jasa- jasa dalam upaya pemberdayaan sumber daya alam serta sumber daya manusia dalam pengelolaannya.

Kebijaksanaan pemerintah dalam pengembangan usaha mikro kecil menengah (UMKM) dalam jangka panjang bertujuan untuk meningkatkan potensi dan partisipasi aktif UMKM dalam proses pembangunan nasional, khususnya dalam rangka mewujudkan pemerataan pembangunan melalui perluasan lapangan kerja dan peningkatan pendapatan (Priyo, 2006).

Penelitian yang menunjukkan pentingnya Usaha Mikro Kecil Menengah (UMKM) dalam meningkatkan pendapatan negara, yaitu Paramasivan dan Selvam (2013) hasil penelitianya bahwa Usaha Mikro, Kecil dan menengah merupakan tulang punggung pembangunan ekonomi negara menunjukkan bahwa untuk 
memenuhi kebutuhan lokal serta tuntutan global yang memiliki keunikan karakter dari produk dan jasa.

Berangkat dari permasalahan di atas, peneliti tertarik untuk melakukan penelitian tentang "Pengaruh Pertumbuhan Ekonomi dan UMKM Terhadap Pendapatan Asli Daerah Kabupaten Bangkalan”

\section{METODE PENELITIAN}

Pendekatan yang digunakan dalam penelitian ini adalah pendekatan kuantitatif. Variabel dalam penelitian ini adalah pertumbuhan ekonomi $\left(\mathrm{X}_{1}\right)$, dan Usaha Mikro Kecil menengah $\left(\mathrm{X}_{2}\right)$ sebagai variabel bebas, dan Pendapatan Asli Daerah (Y) sebagai variabel terikat. Populasi dalam penelitian ini adalah semua pertumbuhan ekonomi yang terdiri dari sembilan indikator yaitu: pertanian, pertambangan dan penggalian, industri pengolahan, listrik, gas dan air bersih, pembangunan, perdagangan, hotel dan restoran, pengangkutan dan komunikasi, keuangan, persewaan dan jasa perusahaan, dan jasa- jasa. Untuk populasi UMKM meliputi keseluruhan jumlah usaha mikro, usaha kecil dan usaha menengah Kabupaten Bangkalan sedangkan populasi PAD berupa pajak daerah, hasil retribusi daerah, hasil perusahaan milik daerah, dan hasil pengelolaan kekayaan daerah yang dipisahkan dan lain-lain pendapatan asli daerah yang sah Kabupaten Bangkalan. Sedangkan sampel yang diambil dari ketiga varibel tersebut yakni dari tahun 2004 sampai 2013 dengan menggunakan teknik sampling purposive sample.

Teknik pengumpulan data yang digunakan dalam penelitian ini adalah dokumentasi. hasil dokumentasi yakni berupa pendapatan asli daerah, pertumbuhan ekonomi meliputi sembilan sektor, dan jumlah usaha mikro kecil menengah.

\section{HASIL PENELITIAN DAN PEMBAHASAN}

Berdasarkan hasil pengumpulan data selama kurun waktu 10 tahun dari tahun 2004 - 2013 menunjukkan bahwa pertumbuhan ekonomi mengalami fluktuatif yakni dari 4,73 persen pada tahun 2004 meningkat menjadi 6,46 pada tahun 2013. Dan jika dibandingkan dari kesembilan sektor pertumbuhan ekonomi, maka menunjukkan sektor perdagangan, hotel dan restoran merupakan sektor tertinggi pencapaian persentase usahanya yaitu 9,36\% pada tahun 2013 dan sektor pertanian merupakan sektor terendah dalam pencapaiannya yaitu 4,74 . Hal ini dikarenakan sebagian masyarakat lebih memilih mencari pekerjaan keluar kota bahkan keluar negeri sebagai Tenaga Kerja Indonesia dibandingkan mengolah SDA yang ada di desa maupun kota Bangkalan. Meningkatnya sektor perdagangan, hotel dan restoran ini karena di Kabupaten Bangkalan banyak mendirikan usaha- usaha perdagangan baik berupa batik maupun usaha di bidang makanan yang banyak diminati baik masyarakat Bangkalan maupun luar Bangkalan.

Model regresi yang diperoleh berdasarkan hasil penelitian dapat dituliskan dalam bentuk persamaan regresi sebagai berikut :

$\mathrm{Y}=-149229092062.401+32565137103.322 \mathrm{X}_{1}+210401.794 \mathrm{X}_{2}$

Berdasarkan hasil persamaan analisis regresi linier berganda tersebut dapat diinterpretasikan sebagai berikut: 1) Nilai konstanta (a) sebesar - 
149229092062.401 artinya jika terjadi perubahan nilai variabel pertumbuhan ekonomi $\left(\mathrm{X}_{1}\right)$ dan UMKM $\left(\mathrm{X}_{2}\right)$ maka Pendapatan Asli Daerah (Y) yang akan terjadi sebesar 0. 2) Koefisien regresi pertumbuhan ekonomi $\left(\mathrm{X}_{1}\right)$ sebesar 32 juta artinya jika variabel pertumbuhan ekonomi $\left(\mathrm{X}_{1}\right)$ naik 1 satuan sedangkan variabel UMKM tetap Pendapatan Asli Daerah (Y) akan mengalami kenaikan sebesar 32 juta. Tanda $(+)$ positif menunjukkan adanya hubungan searah antara pertumbuhan ekonomi dan Pendapatan Asli daerah. Jika pertumbuhan ekonomi tinggi maka Pendapatan Asli Daerah juga akan tinggi. 3) Koefisien regresi dari UMKM ( $\left.\mathrm{X}_{2}\right)$ sebesar 210401.794, artinya jika variabel UMKM $\left(\mathrm{X}_{2}\right)$ naik 1 satuan sedangkan variabel pertumbuhan ekonomi tetap, maka Pendapatan Asli Daerah (Y) akan mengalami kenaikan sebesar 21 juta Tanda $(+)$ positif menunjukkan adanya hubungan searah antara UMKM dan Pendapatan Asli daerah. Jika jumlah UMKM tinggi maka Pendapatan Asli Daerah juga akan tinggi.

\section{a. Uji F (Simultan)}

Uji F bertujuan untuk menunjukkan apakah semua variabel independen yaitu pertumbuhan ekonomi dan Usaha Mikro Kecil Menengah yang dimasukkan ke dalam model mempunyai pengaruh secara bersama-sama terhadap variabel dependen yaitu pendapatan asli daerah. Adapun hasil uji $\mathrm{F}$ dengan SPSS 22 for windows adalah sebagai berikut:

Tabel 1. Hasil Uji F

ANOVA ${ }^{\mathrm{a}}$

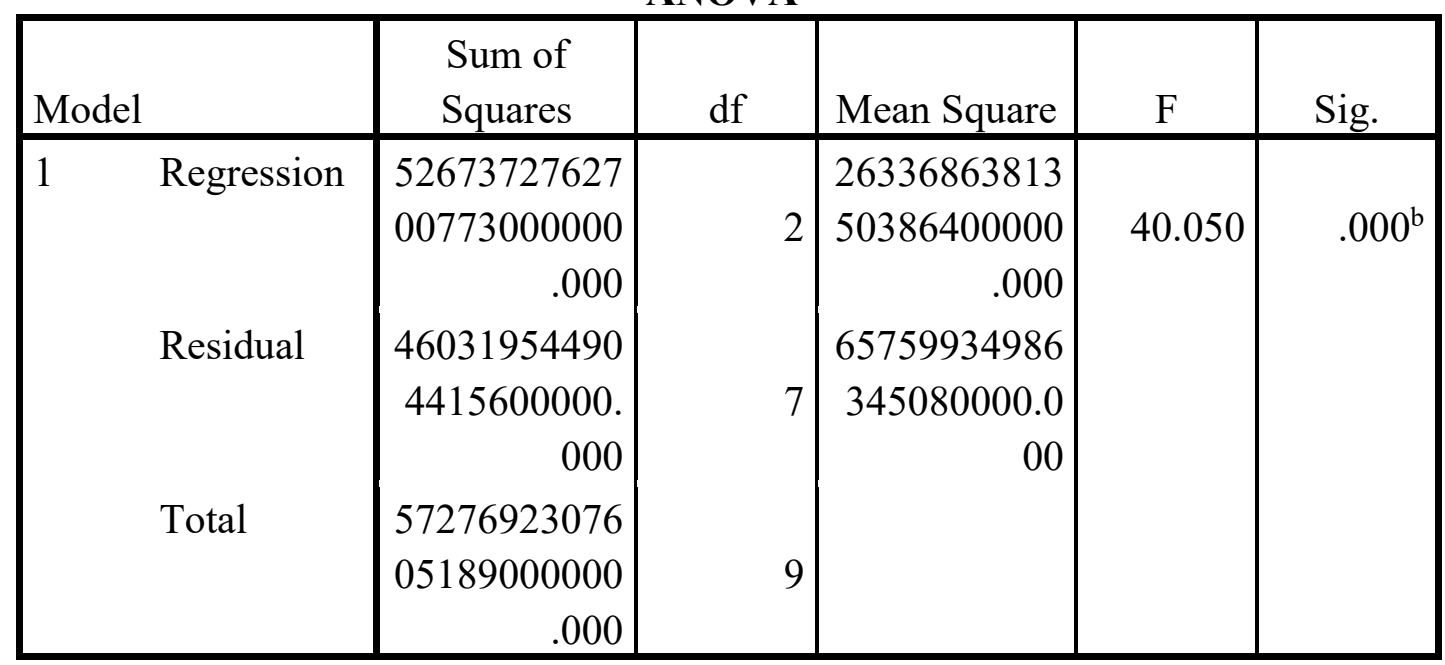

a. Dependent Variable: Y

b. Predictors: (Constant), X1, X2

(Sumber: data sekunder yang diolah, 2015)

Dalam tabel 1 terlihat nilai $\mathrm{F}$ hitung yang dihasilkan adalah sebesar 40,050 dengan tingkat signifikansi lebih kecil dari 5\% yaitu 0,000. Sehingga dapat disimpulkan bahwa variabel independen yaitu pertumbuhan ekonomi $\left(\mathrm{X}_{1}\right)$ dan Usaha Mikro Kecil Menengah $\left(\mathrm{X}_{2}\right)$ berpengaruh secara signifikan terhadap variabel Pendapatan Asli Daerah. Berarti Ho ditolak dan Ha diterima. Besarnya pengaruh pertumbuhan ekonomi $\left(\mathrm{X}_{1}\right)$ dan Usaha Mikro Kecil Menengah $\left(\mathrm{X}_{2}\right)$ secara simultan terhadap Pendapatan Asli daerah dapat dilihat dari Adjused R- square yaitu: 
Tabel 2. Model Summary

\begin{tabular}{|l|r|r|r|r|}
\hline Model & \multicolumn{1}{|c|}{$\mathrm{R}$} & R Square & \multicolumn{1}{c|}{$\begin{array}{c}\text { Adjusted R } \\
\text { Square }\end{array}$} & $\begin{array}{c}\text { Std. Error of } \\
\text { the Estimate }\end{array}$ \\
\hline 1 & $.943^{\mathrm{a}}$ & .890 & .858 & 801889.45658 \\
\hline
\end{tabular}

(Sumber : data diolah, 2015)

Nilai koefisien determinasi (adjusted R-square) yaitu sebesar 0,858, hal ini menggambarkan bahwa Pendapatan Asli Daerah dipengaruhi oleh pertumbuhan ekonomi dan Usaha Mikro Kecil Menengah sebesar 85,8\% sedangkan $14,2 \%$ dipengaruhi oleh faktor-faktor lain selain variabel penelitian tersebut.

\section{b. Uji t (Parsial)}

Nilai t-hitung diketahui sebagai berikut:

1) Hasil perhitungan variabel pertumbuhan ekonomi (X1) menunjukkan 5.180 dengan nilai signifikansi sebesar 0,001 yang menunjukkan $<$ taraf signifikansi $\alpha=0,05$, sehingga dapat disimpulkan bahwa variabel pertumbuhan ekonomi secara parsial berpengaruh signifikan terhadap Pendapatan Asli Daerah.

2) Hasil perhitungan variabel Usaha Mikro Kecil Menengah (X2) menunjukkan nilai sebesar 0,652 dengan nilai signifikansi sebesar 0,535 yang menunjukkan $>$ taraf signifikansi $\alpha=0,05$, sehingga dapat disimpulkan bahwa variabel Usaha Mikro Kecil Menengah (X2) secara parsial tidak berpengaruh terhadap Pendapatan Asli Daerah.

Berdasarkan hasil analisis pengujian dengan menggunakan SPSS 22 for windows menunjukkan bahwa pertumbuhan ekonomi berpengaruh signifikan terhadap Pendapatan Asli daerah Kabupaten Bangkalan. Hal ini memberikan pengertian bahwa semakin tinggi atau positif pertumbuhan ekonomi maka akan diiringi dengan meningkatnya Pendapatan Asli Daerah Kabupaten Bangkalan. Demikian pula sebaliknya, semakin rendah atau negatif pertumbuhan ekonomi maka semakin rendah Pendapatan Asli daerah Kabupaten Bangkalan.

Hal ini dapat dilihat dari perkembangan pertumbuhan ekonomi selama sepuluh tahun yang dikelompokkan dalam tiga kelompok. Kelompok pertama meliputi pertanian, pertambangan dan penggalian diperoleh hasil bahwa selama sepuluh tahun pertambangan dan penggalian merupakan sektor tertinggi. Kelompok kedua meliputi sektor listrik, gas dan air bersih, bangunan dan perdagangan, hotel dan restoran diperoleh hasil bahwa sektor bangunan merupakan sektor tertinggi. Kemudian kelompok ketiga meliputi pengangkutan dan komunikasi, keuangan, persewaan dan jasa perusahaan dan jasa- jasa diperoleh hasil bahwa sektor jasa- jasa merupakan sektor tertingggi dibandingkan ketiga sektor. Dari kesembilan sektor tersebut diperoleh hasil bahwa pertumbuhan ekonomi mengalami peningkatan dari 2004-2007 akan tetapi mengalami penurunan pada tahun 2008 dan mengalami peningkatan kembali dari 2009 sampai 2013. 
Hal ini sesuai dengan teori Thomas Robert Malthus mengemukakan bahwa ukuran keberhasilan pembangunan suatu perekonomian adalah kesejahteraan negara, yaitu jika PNB potensialnya meningkat. Sector dominan adalah pertanian dan industri. Jika dikedua output di kedua sector tersebut ditingkatkan maka PNB potensialnya akan bisa ditingkatkan. Menurut Thomas Robert Malthus ada dua faktor yang sangat menentukan pertumbuhan, yaitu: a) Faktor-faktor ekonomi seperti tanah, tenaga kerja, modal, dan organisasi, dan b) Faktor-faktor non-ekonomi meliputi keamanan atas kekayaan, konstitusi dan hukum yang pasti, etos kerja dan disiplin pekerja yang tinggi.

Keadaan tersebut sesuai dengan hasil penelitian yang dilakukan oleh Gunantara \& Dwirandra(2014), Iswara \& dan Indrajaya (2014) yang menyimpulkan bahwa pertumbuhan ekonomi secara parsial berpengaruh terhadap pendapatan asli daerah.

Hasil penelitian ini juga sesuai dengan penelitian sebelumnya yang dilakukan oleh Akintoye (2013), Sasana (2009), Taha dkk (2011) dan Indarti \& Sugiartiana (2012) yang menyatakan bahwa pertumbuhan ekonomi yang baik dapat meningkatkan pendapatan asli daerah. Adanya perbedaan dan kesamaan hasil penelitian ini tentunya tidak terlepas dari keadaan atau kondisi geologi, sosial dan perekonomian suatu daerah.

Dengan demikian hipotesis yang menyatakan bahwa diduga ada pengaruh pertumbuhan ekonomi terhadap pendapatan asli daerah Kabupaten Bangkalan maka H0 ditolak dan Ha diterima

Selanjutnya, berdasarkan hasil perolehan data dari Dinas Industri dan UMKM Kabupaten Bangkalan maka diperoleh jumlah UMKM dalam kurun waktu sepuluh tahun terus mengalami peningkatan hingga mencapai 121.611 pada tahun 2013 dengan perincian jumlah usaha mikro 111. 874, jumlah usaha mikro 9. 642 dan usaha menengah dengan jumlah 94 unit. Dari ketiga jenis usaha maka yang mengalami peningkatan cukup besar yakni pada usaha mikro yang mencapai 111. 874 pada tahun 2013 dengan porsentase 91, 97\%. Perbedaan jumlah yang sangat jauh antara usaha mikro, usaha kecil dan usaha menengah hal ini karena terkendala akan modal yang harus dikeluarkan oleh para pengusaha dalam mengembangkan usahanya.

Berdasarkan hasil penelitian menunjukkan bahwa variabel $\mathrm{UMKM}\left(\mathrm{X}_{2}\right)$ secara parsial tidak berpengaruh terhadap Pendapatan Asli Daerah karena hasil signifikan $>$ dari 0,05 yakni 0,535 . Keadaan tersebut tidak sesuai dengan teori yang diungkapkan oleh Tambunan (2012) yang menyatakan bahwa Usaha Mikro Kecil Menengah dapat menggerakkan asset uang yang dimiliki masyarakat menjadi suatu bentuk usaha yang produktif, dimana semakin bertambahnya jumlah Usaha Mikro Kecil Menengah dapat meningkatkan pendapatan asli daerah. Dengan kata lain Usaha Mikro Kecil Menengah memiliki pengaruh negative terhadap Pendapatan Asli Daerah. Semakin tinggi Usaha Mikro Kecil Menengah maka semakin rendah Pendapatan Asli Daerah yang tercipta.

Sehingga dapat dikatakan bahwa adanya peningkatan Usaha Mikro Kecil Menengah tidak dapat menjamin meningkatnya Pendapatan Asli Daerah Kabupaten Bangkalan karena tidak sesuai dengan teori dan penelitian terdahulu yang menyebutkan semakin tinggi jumlah Usaha Mikro Kecil 
Menengah maka semakin rendah Pendapatan Asli Daerah. Tidak adanya pengaruh signifikan dalam penelitian ini dapat disebabkan oleh berbagai faktor, diantaranya karena sebagian masyarakat yang bergerak dibidang usaha kecil masih kurang sadar untuk membayar pajak. Selain itu juga mahalnya pungutan pajak yang harus ditanggung oleh pengusaha menengah dalam memulai usahanya sehingga jumlah usaha menengah di Kabupaten bangkalan mengalami penurunan dari 2010- 2013.

Hal ini tidak sesuai dengan hasil penelitian yang dilakukan oleh Paramasivan \& Selvam (2013) yang menyatakan bahwa Usaha Mikro Kecil Menengah merupakan tulang punggung serta memberikan kontribusi dalam mengembangkan pendapatan negara India. Oleh karena itu hipotesis yang menyatakan diduga ada pengaruh UMKM terhadap Pendapatan Asli Daerah Ha diterima.

Berdasarkan hasil pengumpulan data yang diperoleh dari Dinas Pendapatan Kabupaten Bangkalan diketahui bahwa pendapatan asli daerah Kabupaten Bangkalan cukup fluktuatif setiap tahunnya. Pada tahun 2004 pendapatan Kabupaten Bangkalan hanya mencapai 20.568.365.524,22 akan tetapi pada tahun 2013 Pendapatan Asli Daerah Kabupaten Bangkalan mencapai 92.463.196.301,85. Hanya kurang 2.744.579.025,87 dari target yang sudah ditetapkan kabupaten Bangkalan.

Berdasarkan hasil analisis pengujian dengan menggunakan SPSS 22 for windows pertumbuhan ekonomi dan Usaha Mikro Kecil Menengah berpengaruh secara signifikan terhadap Penadapatan Asli Daerah. Hasil penelitian ini sesuai hasil penelitian yang dilakukan oleh Paramasivan \& Selvam(2013) yang mendapati hasil bahwa Usaha Mikro Kecil Menengah dapat meningkatkan pendapatan suatu negara. Hal ini juga didukung dengan hasil penelitian yang dilakukan oleh Gunantara \& Dwirandra (2014) menyatakan bahwa pertumbuhan ekonomi ekonomi yang baik dapat meningkatkan pendapatan asli daerah.

Berdasarkan analisa data didapati hasil yang menunjukkan bahwa hubungan pertumbuhan ekonomi dan Usaha Mikro Kecil Menengah terhadap PAD memiliki koefisien determinasi sebesar 0,858. Hal ini menggambarkan bahwa Pendapatan Asli Daerah dipengaruhi oleh pertumbuhan ekonomi dan Usaha Mikro Kecil Menengah sebesar 85,8\% sedangkan 14,2\% dipengaruhi oleh factor-faktor lain selain variabel penelitian tersebut. Dari hasil uji $\mathrm{F}$ diperoleh F-hitung sebesar 40,050 dengan tingkat signifikansi lebih kecil dari $5 \%$ yaitu 0,000 . Hal ini menunjukkan bahwa variabel independen yaitu pertumbuhan ekonomi dan UMKM berpengaruh secara signifikan terhadap variabel pendapatan asli daerah. Dengan demikian, hipotesis yang menyatakan bahwa ada pengaruh antara pertumbuhan ekonomi dan Usaha Mikro Kecil Menengah terhadap pendapatan ditolak.

\section{KESIMPULAN}

Berdasarkan penelitian yang telah dilakukan, beberapa kesimpulan yang dapat diambil sebagai berikut: Ada pengaruh signifikan pertumbuhan ekonomi terhadap Pendapatan Asli Daerah Kabupaten Bangkalan serta memiliki hubungan positif. Artinya semakin tinggi pertumbuhan ekonomi 
maka semakin tinggi pendapatan asli daerah, begitu pula sebaliknya, usaha Mikro Kecil Menengah berpengaruh negatif terhadap Pendapatan Asli Daerah Kabupaten Bangkalan. Artinya semakin tinggi UMKM maka PAD semakin rendah, dan ada pengaruh signifikan pertumbuhan ekonomi dan UMKM terhadap Pendapatan Asli Daerah. Hal ini menggambarkan bahwa kedua variabel independen tersebut memberikan kontribusi atau implikasi dalam Pendapatan Asli Daerah.

Dari hasil penelitian tersebut, maka diajukan beberapa saran sebagai berikut: diharapkan pemerintah Kabupaten Bangkalan tetap menjaga laju pertumbuhan ekonomi serta berusaha meningkatkan kesembilan sektor terutama sektor pertanian karena pertanian merupakan mata pencaharian masyarakat Bangkalan, masyarakat Bangkalan yang merasa kesulitan dalam memulai atau mengembangkan usaha menengah untuk memilih usaha mikro atau usaha kecil dengan meningkatkan kualitas produk yang dihasilkan sehingga menghasilkan omset yang lebih besar, perlunya sosialisasi wajib membayar pajak terhadap pengusaha mikro karena pajak tersebut nantinya akan kembali ke masyarakat dalam bentuk fasilitas yang disediakan oleh Pemerintah Kabupaten Bangkalan., dan diharapkan pemerintah Kabupaten Bangkalan tetap memperhatikan Usaha Mikro Kecil Menengah yang ada di Kabupaten Bangkalan sekalipun secara empiris tidak berpengaruh terhadap Pendapatan Asli Daerah karena Usaha Mikro Kecil Menengah merupakan usaha secara individu yang dapat mengurangi ketergantungan masyarakat terhadap pemerintah.

\section{DAFTAR RUJUKAN}

Ad, Priyo. H. (2006). Hubungan Antara Pertumbuhan Ekonomi Daerah, Belanja Pembangunan Daerah dan Pendapatan Asli Daerah(Studi Pada Kabupaten dan Kota se Jawa- Bali). E-JURNAL EKONOMI , 2, 6-12.

Akintoye, I.R, Tashi, G.A. (2013). The Effect of Tax Compliance on Economic Growth and Development in Nigeria, West Africa. British Journal of Arts and Social Sciences, 11(II), 222- 231.

Arwati, D, Hadiati, N. (2013, Juni). Pengaruh Pertumbuhan Ekonomi, Pendapatan Asli Daerah dan Dana Alokasi Umum terhadap Pengalokasian Anggaran Belanja Modal pada Pemerintah Daerah Kabupaten/Kota di Jawa tengah. 2(II), 200-210.

Paramasivan, C. P \& Mari S. (2013, April). Progress and Performance of Micro, Small and Medium Entreprises in India. International Journal of Manajement Studies, 2(4).

Erwin T \& Rogahang. (2013, April). Pengaruh Modal Sosial terhadap Perilaku Kewirausahaan Suatu Studi pada Pelaku UMKM pada Kecamatan kebaruan Kabupaten Kepulauan Talaud. 1(2).

I Made Anom Iswara, I Gusti Bagus Indrajaya . (2014). Pengaruh Pendapatan Asli Daerah, Pendapatan Perkapita, dan Tingkat Pendidikan terhadap Tingkat Kemiskinan di Provinsi Bali tahun 2006- 2011. E- Jurnal EP Unud , 3 , no 11.

Iin Indarti, Sugiartiana. (2012). PEngaruh Pertumbuhan Ekonomi, Pendapatan Asli Daerah, Dana Alokasi Umum terhadap Pengalokasian Anggaran 
Belanja Modal di Kota Semarang Periode tahun 2005-2009. Fokus Ekonomi , 7 No 2, 1-15.

Mawarni, Darwanis, Syukriy A. (2013). Pengaruh Pendapatan Asli Daerah dan Alokasi Umum terhadap Belanja Modal serta Dampaknya terhadap Pertumbuhan Ekonomi Daerah. Jurnal Akuntansi Pascasarjana Universitas Syiah Kuala , 2, No 2, 80-90.

Putu Candra Gunantara, A.A.NB Dwiandra. (2014). Pengaruh Pendapatan Asli Daerah dan Dana Alokasi Umum pada Pertumbuhan Ekonomi dengan Belanja Modal sebagai Variabel Pemoderasi di Bali. . Jurnal Akuntansi Universitas Udayana , 7, 529-546.

Roshaiza Taha, Loganathan, Nanthakumar, Sisira R.N. Colombage. (2011). The Effect of Economic Growth on Taxation Revenue: The Case of a Newly Industrialized Country. International Review of Business Research Papers , 7, 319- 329 .

Sasana, H. (2009). Analisis Dampak Pertumbuhan Ekonomi, Kesenjangan antar Daerah dan Tenaga Kerja Terserap terhadap Kesejahteraan di Kabupaten/Kota Provinsi Jawa Tengah. Jurnal Bisbis dan Ekonomi (JBE), 16 (1), 50- 69.

Suryana. (2000). Ekonomi Pembangunan Problematika dan Pendekatan. Jakarta: Salemba Empat.

Syarif Hidayatullah, Thomas Djaka SBW. (2011). Model Pemberdayaan Masyarakat Melalui Pengembangan Ekonomi Lokal (Studi pada UKM di Kota Malang). Jurnal Ekonomi , 4 (1), 65-75.

Tambunan, T. T. (2012). Perekonomian Indonesia Kajian Teoti dan Analisis Empiris . Bogor: Ghalia Indonesia.

(2004). UU RI No. 33 Tahun 2004 Tentang Perimbangan Keuangan antara Pemerintah Pusat dan Pemerintah Daerah.

Waluyo, Eko. (2009). Ekonomi Makro (Edisi Revisi ed.). Malang: Umm Press. 